\title{
26. TEXTURAL AND COMPOSITIONAL VARIATIONS IN DOLERITE UNITS FROM HOLE 395A
}

\author{
G. Propach, S. Lee, and E. Prosser, Mineralogisch-Petrographisches Institut der Universität München, \\ Theresienstr. 41, D-8000 München 2, F.R.G.
}

\section{INTRODUCTION}

The section of tholeiitic dolerite recovered from Hole $395 \mathrm{~A}$ is of special interest because it is an almost continuously cored formation, 16 meters thick, whose contact relationships are, for the most part, well preserved.

The aim of this study was to examine the relationship between the dolerites and surrounding rocks and to determine to what extent, and in which respects, these dolerites can be related to continental occurrences. Specific aspects discussed here are compositional and textural variations, differentiation effects, and cooling behavior.

The location of samples and stratigraphic relationships in this segment of Hole 395A are given in Figures 1 and 2 .

\section{PETROGRAPHY}

\section{Contact Relationships}

The dolerite section discussed here occurs at about 610 meters sub-bottom and is bounded above and below by the aphyric basalts of core Sections 61-1 and 64-2. This segment (see Figure 1) is made up of upper and lower dolerite units having cored lengths of 4.2 and 10.4 meters, respectively. These two units are separated by a layer of fine-grained, aphyric basalt, 50 cm thick.

Fine-grained marginal dolerite facies were recovered from three of the four dolerite-aphyric basalt contacts. The fourth contact, the base of the upper dolerite unit, was not recovered. Only one of the first three contacts mentioned was continuously cored and fully recovered. This contact is represented by the basal chilled margin of the lower dolerite unit (Sample 64-2, 129-132 cm), basaltic glass fragments (Sample 64-2, $133 \mathrm{~cm}$ ), and aphyric basalt. The possibility that the basalt glass might belong to the chilled margin of the dolerite (Initial Core Descriptions) is slight, since the chemical composition of this glass (microprobe data, Melson, this volume) resembles more closely that of the underlying aphyric basalts than that of the dolerite.

\section{Mineral Constituents}

The minerals present in the dolerite can be classified according to their order of crystallization. The successive stages can be summarized as follows:

First stage, Phenocrysts:

Plagioclase, olivine, clinopyroxene, chromite.

Main stage, Groundmass:
Plagioclase, clinopyroxene, olivine, titanomagnetite, Mesostasis: ${ }^{1}$

Sodic plagioclase, clinopyroxene, titanomagnetite, ilmenite, apatite,

sulfide globules, glass.

Postmagmatic stage, Alteration minerals:

Brown, green, pale green hornblende, phillipsite, saponite, chlorite, low quartz, goethite, calcite.

\section{Grain Size: Phenocrysts}

Sinking or floating behavior of the phenocrysts and the corresponding changes in grain size cannot be reliably determined through mean diameter measurements, because a large portion of the smaller phenocrysts is often camouflaged by the groundmass components of the dolerites. Thus, only the maximum diameters of the individual phenocryst minerals in individual samples (thin sections and polished rock slabs) were chosen to demonstrate grain size changes. Plots of these measurements along the profile produced very erratic curves. These were smoothed by integrating measurements of two or three adjacent samples.

As can be seen in Figure 1a, there is no significant variation in the maximum diameters of the clinopyroxene phenocrysts. The same holds true for olivine, with the possible exception of the upper margin of the lower dolerite unit, where depletion of the larger phenocrysts may have occurred. Also noteworthy in this respect is that the olivine phenocryst diameters are largest in the outermost margins and decrease sharply in the submarginal zones. Such distribution behavior contrasts with that of continental occurrences and experimental results (Bhattacharji, 1967). Phenocrysts would be expected to concentrate in the median portions of the flowing magma.

The plagioclase phenocrysts are larger in the median zones of the dolerite units than in the margins. The less calcic outer zones of these phenocrysts are less than $0.15 \mathrm{~mm}$ in width, so that post-intrusive growth cannot have contributed to any great extent to the total length of the phenocrysts. This accumulation of larger phenocrysts could have resulted from the effects of flow differentiation (Bhattacharji, 1967).

\section{Grain Size: Groundmass}

The main trend of grain size variation in the dolerites-chilled margins giving way to coarser grained

\footnotetext{
${ }^{1}$ The mesostasis is here defined as the very fine grained interstitial material between the groundmass crystals.
} 

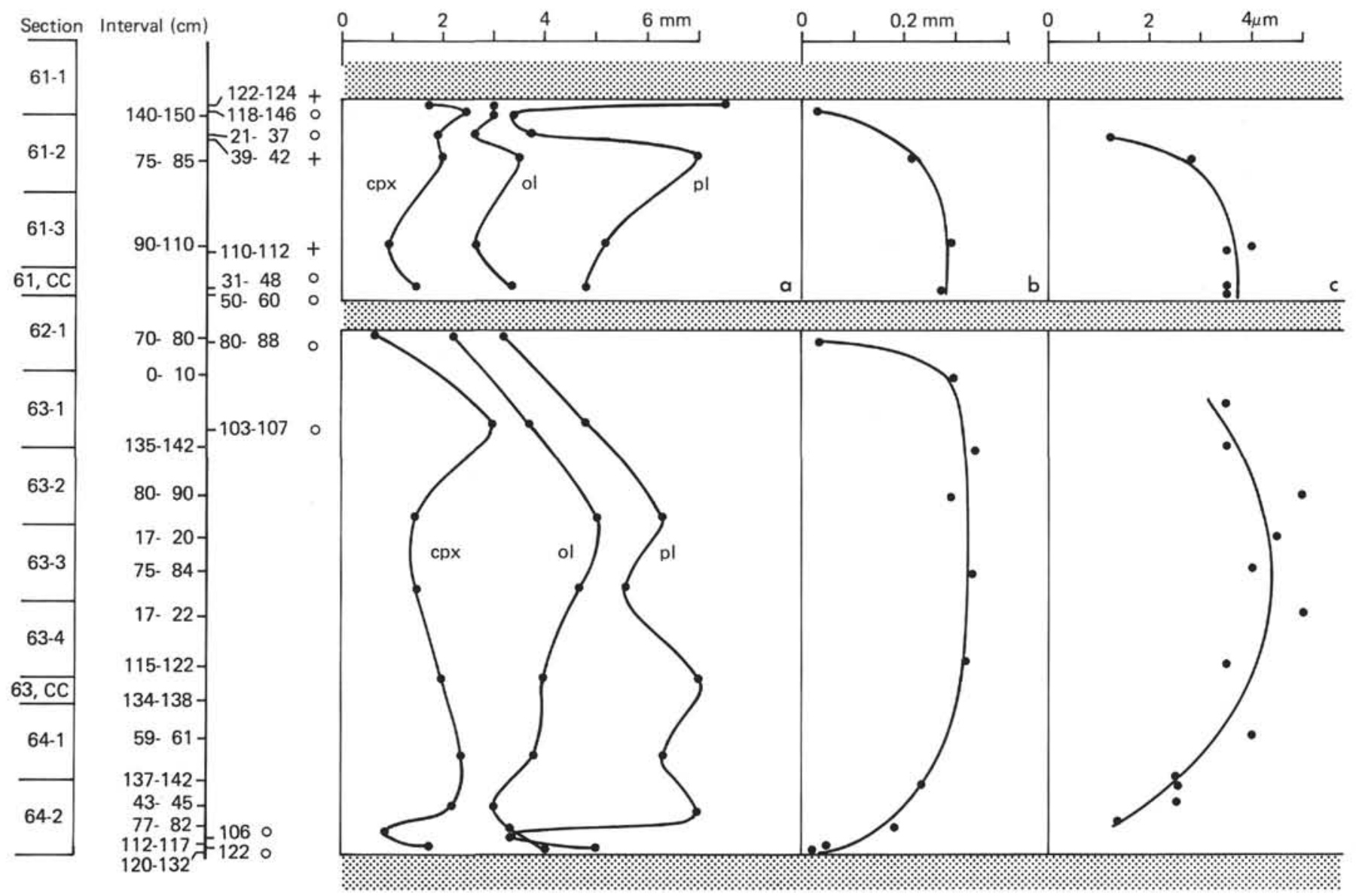

Figure 1. (A) Maximum phenocryst lengths for clinopyroxene, olivine and plagioclase. Data from two to three samples have been combined to obtain more representative figures. Small humps in the curves are meaningless. (B) Mean grain size of groundmass clinopyroxenes. (C) Maximum diameters of apatite needles in the mesostasis Shaded areas represent phyric basalt units. Munich sample numbers are listed on the left of the second vertical line, DSDP and British Museum samples are represented by crosses and circles, respectively, and are to the right.

interior portions-is described in Chapter 7 (this volume). A more detailed analysis was achieved by measuring the mean diameters of the groundmass clinopyroxenes.

Clinopyroxene proved most suitable for this purpose, since it is fresher than the olivines, more regular in shape than the plagioclases and titanomagnetites, forms few microphenocrysts, and is ubiquitous throughout the dolerite.

The results of these measurements are plotted in Figure $1 \mathrm{~b}$. The curves are roughly symmetric, but loss of core and the resultant shortening of true section distorts the $\mathrm{m}$. The basal 3 meters of the lower dolerite unit were recovered continuously, and the shape of the corresponding curve would seem to be representative of the true crystallization trend, which in turn would reflect the course of the cooling trend.

\section{Modal Composition}

Dolerite samples adjacent to the uppermost and lowest contacts (Table 1, No. 1 and 2) show strong enrichment in phenocryst content. This cannot be the result of simple floating or sinking behavior, since both plagioclase and olivine are enriched in the basal as well as roof margins. The amount of olivine that may have been added to the basal margin through crystal settling is small: the rate of increase in phenocryst content from sub-marginal to marginal zones is almost equal for both the tops and bottoms of the dolerite sills.

Samples from the sub-marginal zones of the uppermost and lowest contacts (Table 1, No. 4 and 5), as well as samples from the uppermost recovered part of the lower unit (Table 1, No. 3) are almost identical in composition. The proportion of phenocryst content in the sub-marginal zones is similar to that of the porphyritic basalts (Table 1, No. 6) which, according to the Initial Core Descriptions, are the chemical equivalents of the dolerites.

The lack of any noticeable selective depletion of phenocrysts in the upper part or accumulation of the same in the lower part of the dolerites indicates rapid solidification, to such an extent that crystal movement was inhibited. Phenocrysts of olivine or clinopyroxene of the size found in the dolerites (up to $5 \mathrm{~mm}$, see Figure 1a) would sink with a velocity of a few centi- 


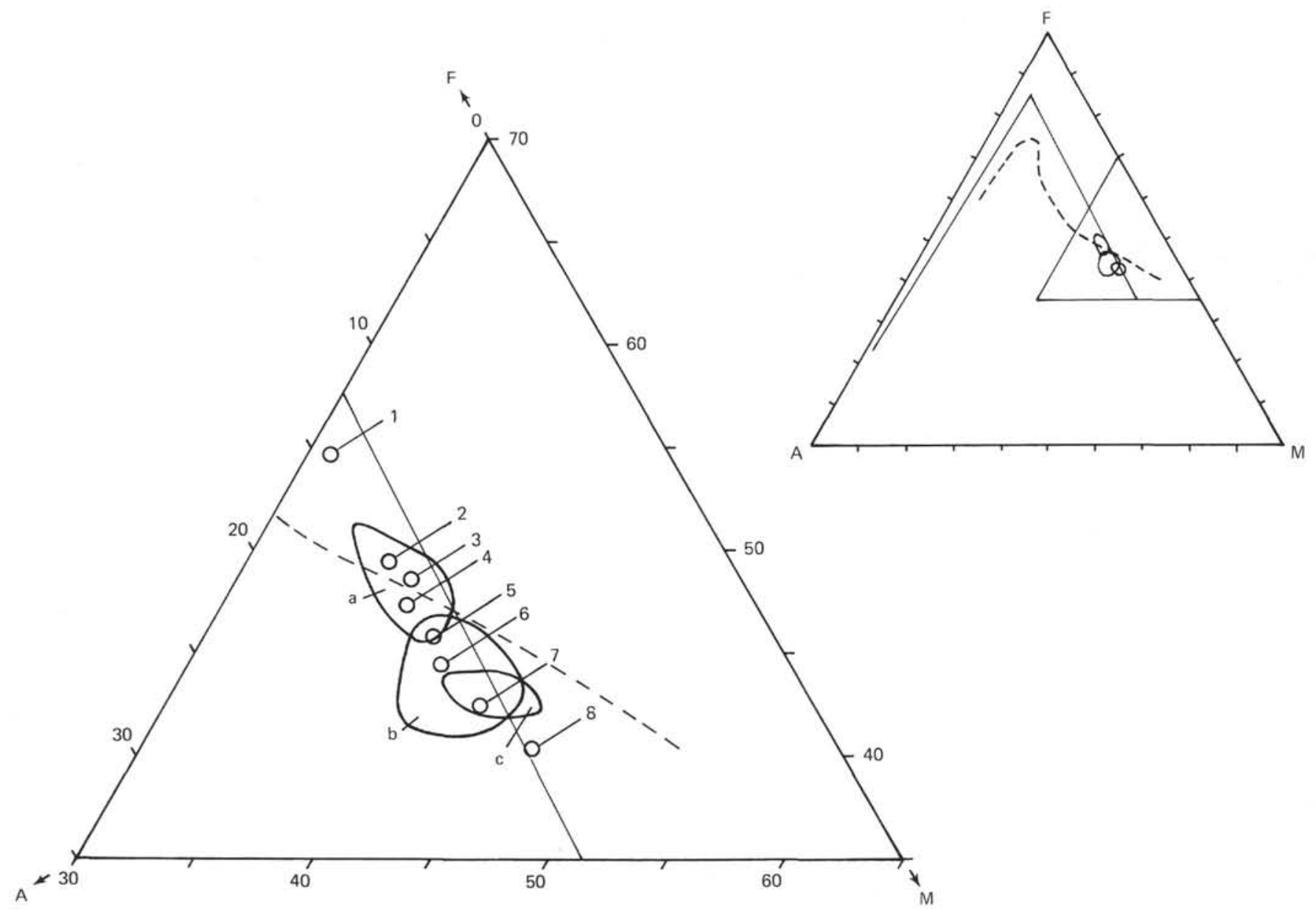

Figure 2. A-F-M plot of sample groups from Hole 395A. $a=$ aphyric basalts, $b=$ phyric basalts, $c=$ dolerites from core sections 61-1 to 64-2. $l=$ late chilled dolerite, Palisades sill., $2=$ chilled basal dolerite, Palisades sill., $3=$ average tholeiite, Prinz et al., 1976., 4 = average aphyric basalt (395A), 5 = average dolerite, Palisades, 6 = average phyric basalt (395A), $7=$ average dolerite (395A), $8=$ lower chilled margin, lower dolerite (395A) Solid and dashed lines represent the Skaergaard and Palisades differentiation trends, respectively.

ters per hour (Shaw, 1965). The accumulation of noticeable amounts of olivine could thus take place within a few hours. Calculations on the basis of data given by Jaeger (1968) indicate that even such a short interval was not available in the margins. The drop in temperature from $1150^{\circ}$ to $1100^{\circ} \mathrm{C}$ (where crystal sinking is assumed to cease because of lack of free space) occurs over an interval of 35 to 0.6 hours, respectively, at corresponding distances from the contacts of 1 meter and 0.1 meter. The presumably high water content of the surrounding rocks may have increased cooling rates along the immediate contacts. Rapid cooling is further indicated by the persistence of the undevitrified glass from the subjacent aphyric basalts in immediate contact with the overlying chilled margin of the dolerites.

\section{Mesostasis}

The mean amount of mesostasis occurring in nine dolerite samples from the lower dolerite unit is given in Table 1, No. 7. Individual plots of these samples are included in Figure 3. Little systematic variation in mesostasis content could be observed within the coarser grained median portion of the dolerite. The minimum shown in the lower unit results from the formation of secondary minerals, which is most extensive in this zone and preferentially occurs in the mesostasis.

The minerals in the mesostasis are plagioclase (An near $30 \%$, high-temperature properties), acicular clinopyroxene, apatite needles, titanomagnetite, ilmenite, and sulfide globules. A felty aggregate, pale yellow to olive-green, presumably results from devitrification of a residual glass. Clinopyroxenes in the groundmass bordering the mesostasis generally have light brown margins. In one instance, (Sample 63-4, 134-138 cm), the clinopyroxenes show green rims.

Migration of the residual melt, now represented by the apatite-bearing mesostasis, could have caused variations in the phosphate content of the dolerites. Nothing of this kind was found. The steady amounts of phosphorus (see Table 2) merely reflect the modal proportion of the mesostasis in the dolerites. The maximum of the mesostasis curve is tentatively interpreted as being the result of differing cooling rates. Such differences are not visible in the plot of sizes of 
TABLE 1

Average Modal Compositions of Dolerites and

Phyric Basalts From Hole 395A (in vol. \%)

\begin{tabular}{|c|c|c|c|c|c|c|c|}
\hline \multicolumn{4}{|c|}{ Phenocrysts } & \multirow[b]{2}{*}{ Gms } & \multirow[b]{2}{*}{ Ore } & \multirow[b]{2}{*}{ Mss } & \multirow[b]{2}{*}{$\mathrm{Sec}$} \\
\hline & Plag & $\mathrm{Ol}$ & Cpx & & & & \\
\hline 1 & 30.0 & 6.6 & 0.5 & 62.9 & & & \\
\hline 2 & 24.8 & 8.2 & 0.5 & 66.5 & & & \\
\hline 3 & 18.1 & 3.6 & 0.7 & 77.6 & & & \\
\hline 4 & 19.0 & 3.7 & 1.3 & 76.0 & & & \\
\hline 5 & 16.7 & 4.8 & 0.7 & 77.9 & & & \\
\hline 6 & 24.1 & 5.2 & 1.0 & 69.7 & & & \\
\hline 7 & $60.2+2.3$ & $7.5 \pm 1.7$ & $23.2 \pm 2.4$ & & $2.3 \pm 0.9$ & $5.9 \pm 1.4$ & $0.5 \div 0.4$ \\
\hline
\end{tabular}

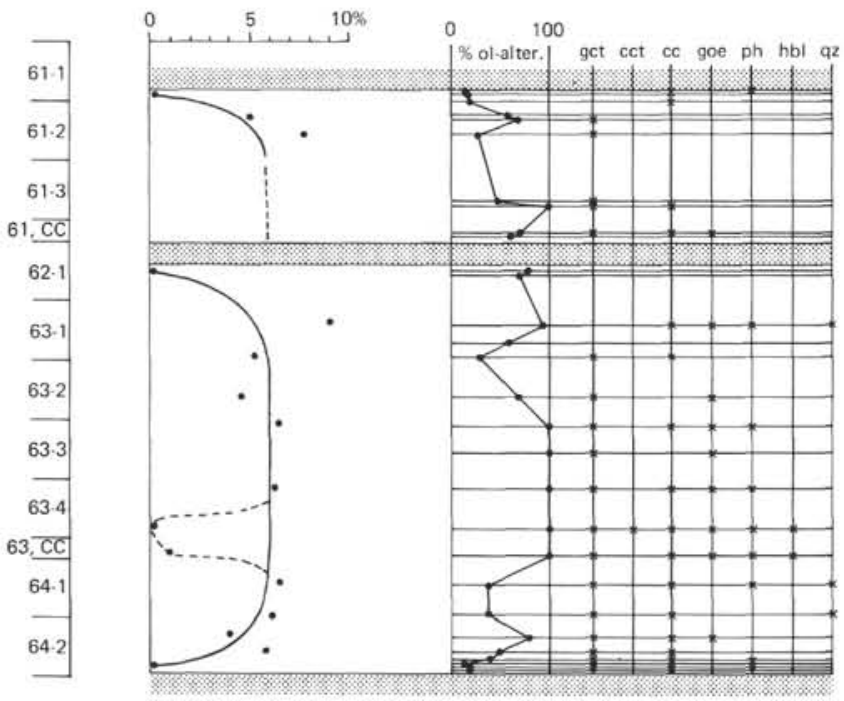

Figure 3. Volume per cent of alteration of olivine (estimated), and presence of secondary minerals. The amount of mesostasis in Sections 63-4 and 63, CC is lowered by secondary mineralization. $\quad c c=$ calcite, $c c t=$ colorless chlorite, gct $=$ green chlorite, goe $=$ goethite, $h b l=$ hornblende, $p h=$ phillippsite, $q z=q u a r t z$. Saponite is present in all samples.

groundmass clinopyroxene (Figure $1 \mathrm{~b}$ ) and diameters of acicular clinopyroxene in the mesostasis (not plotted).

\section{Alteration}

The effects of alteration are most prominent in a zone 3 to 4 meters above the lower contact of the lower sill. Secondary minerals in this zone constitute up to 40 per cent of the total volume. The qualitative mineralogical composition of the secondary mineral assemblages are shown in Figure 3.

Alteration is indicated by the growth of brown hornblende (up to $0.5 \mathrm{~mm}$ in width) on clinopyroxene. The brown hornblende in turn shows terminations of green and pale green hornblende. The total amount of hornblende is less than 0.5 per cent. Phillipsite, mostly as aggregates of radiating fibers, can be found in vugs,
TABLE 2

Dolerite Compositions (per cent) Hole 395A

\begin{tabular}{lrrrrrr}
\hline \multicolumn{7}{c}{ Sample (Interval in cm) } \\
& \multicolumn{7}{c}{$1-1}$, & $61-2$, & $61-3$ & $62-1$, & $63-1$, & $63-1$, \\
& $140-150$ & $75-85$ & $90-110$ & $70-80$ & $0-10$ & $135-142$ \\
\hline $\mathrm{SiO}_{2}$ & 48.63 & 49.06 & 48.69 & 49.59 & 49.33 & 49.04 \\
$\mathrm{TiO}_{2}$ & 1.18 & 1.11 & 1.13 & 1.21 & 1.14 & 1.05 \\
$\mathrm{Al}_{2} \mathrm{O}_{3}$ & 16.44 & 16.96 & 16.61 & 16.30 & 16.95 & 16.72 \\
$\mathrm{Fe}_{2} \mathrm{O}_{3}$ & 3.31 & 2.01 & 2.01 & 3.53 & 1.97 & 3.95 \\
$\mathrm{FeO}$ & 5.23 & 6.36 & 6.50 & 5.07 & 6.20 & 4.62 \\
$\mathrm{MnO}$ & 0.15 & 0.13 & 0.14 & 0.15 & 0.14 & 0.14 \\
$\mathrm{MgO}$ & 8.04 & 8.13 & 8.44 & 7.90 & 8.28 & 8.55 \\
$\mathrm{CaO}$ & 11.79 & 11.78 & 11.98 & 11.92 & 11.65 & 11.85 \\
$\mathrm{Na}_{2} \mathrm{O}$ & 2.68 & 2.55 & 2.35 & 2.39 & 2.38 & 2.18 \\
$\mathrm{~K}_{2} \mathrm{O}$ & 0.16 & 0.10 & 0.09 & 0.15 & 0.09 & 0.14 \\
$\mathrm{P}_{2} \mathrm{O}_{5}$ & 0.12 & 0.11 & 0.12 & 0.08 & 0.11 & 0.11 \\
$\mathrm{H}_{2} \mathrm{O}^{+}$ & 1.48 & 1.21 & 1.49 & 1.12 & 1.25 & 1.07 \\
$\mathrm{H}_{2} \mathrm{O}^{-}$ & 0.80 & 0.50 & 0.44 & 0.59 & 0.51 & 0.93 \\
$\mathrm{~T}^{2}$ & & & & & &
\end{tabular}

Trace elements (ppm)

\begin{tabular}{|c|c|c|c|c|c|c|}
\hline $\begin{array}{l}\mathrm{Rb} \\
\mathrm{Sr} \\
\mathrm{Zr}\end{array}$ & $\begin{array}{l}9 \\
127 \\
65\end{array}$ & $\begin{array}{l}6 \\
135 \\
65\end{array}$ & $\begin{array}{l}5 \\
118 \\
113\end{array}$ & $\begin{array}{l}8 \\
126 \\
104\end{array}$ & $\begin{array}{l}4 \\
125 \\
81\end{array}$ & $\begin{array}{l}6 \\
120 \\
118 \\
\end{array}$ \\
\hline & \multicolumn{6}{|c|}{ Sample (Interval in $\mathrm{cm}$ ) } \\
\hline & $\begin{array}{l}63-2 \\
80-90\end{array}$ & $\begin{array}{c}63-3 \\
75-84\end{array}$ & $\begin{array}{c}63-4, \\
115-122\end{array}$ & $\begin{array}{c}64-1, \\
137-142\end{array}$ & $\begin{array}{l}64-2 \\
77-82\end{array}$ & $\begin{array}{c}64-2, \\
112-117\end{array}$ \\
\hline $\begin{array}{l}\mathrm{SiO}_{2} \\
\mathrm{TiO}_{2} \\
\mathrm{Al}_{2} \mathrm{O}_{3} \\
\mathrm{Fe}_{2} \mathrm{O}_{3} \\
\mathrm{FeO} \\
\mathrm{MnO} \\
\mathrm{MgO} \\
\mathrm{CaO} \\
\mathrm{Na}_{2} \mathrm{O} \\
\mathrm{K}_{2} \mathrm{O} \\
\mathrm{P}_{2} \mathrm{O}_{5} \\
\mathrm{H}_{2} \mathrm{O}^{+} \\
\mathrm{H}_{2} \mathrm{O}^{-}\end{array}$ & $\begin{array}{r}49.16 \\
1.14 \\
16.72 \\
3.10 \\
5.16 \\
0.15 \\
8.14 \\
12.12 \\
2.41 \\
0.13 \\
0.11 \\
1.13 \\
0.53\end{array}$ & $\begin{array}{r}47.57 \\
1.10 \\
17.96 \\
3.43 \\
4.67 \\
0.15 \\
7.32 \\
12.39 \\
2.70 \\
0.12 \\
0.12 \\
1.73 \\
0.75\end{array}$ & $\begin{array}{r}48.04 \\
0.87 \\
16.86 \\
3.51 \\
4.00 \\
0.14 \\
9.09 \\
12.19 \\
2.29 \\
0.09 \\
0.11 \\
1.79 \\
0.96\end{array}$ & $\begin{array}{r}49.16 \\
1.04 \\
17.45 \\
2.49 \\
5.30 \\
0.13 \\
7.90 \\
12.13 \\
2.48 \\
0.11 \\
0.12 \\
1.24 \\
0.40\end{array}$ & $\begin{array}{r}47.71 \\
1.10 \\
17.17 \\
3.29 \\
5.25 \\
0.14 \\
8.30 \\
12.38 \\
2.60 \\
0.11 \\
0.12 \\
1.38 \\
0.71\end{array}$ & $\begin{array}{r}45.69 \\
1.08 \\
15.40 \\
3.28 \\
5.02 \\
0.14 \\
8.42 \\
11.45 \\
2.57 \\
0.14 \\
0.11 \\
1.13 \\
0.47\end{array}$ \\
\hline \multicolumn{7}{|c|}{ Trace elements (ppm) } \\
\hline $\begin{array}{l}\mathrm{Rb} \\
\mathrm{Sr} \\
\mathrm{Zr}\end{array}$ & $\begin{array}{l}9 \\
128 \\
148\end{array}$ & $\begin{array}{l}7 \\
124 \\
109\end{array}$ & $\begin{array}{l}7 \\
118 \\
131\end{array}$ & $\begin{array}{l}9 \\
121 \\
105\end{array}$ & $\begin{array}{l}14 \\
123 \\
102\end{array}$ & $\begin{array}{l}8 \\
129 \\
96\end{array}$ \\
\hline
\end{tabular}

Sample (Interval in cm)

\begin{tabular}{|c|c|c|c|c|c|}
\hline & $\begin{array}{l}395 \mathrm{~A}- \\
64-2 \\
120-132\end{array}$ & $\begin{array}{l}395- \\
17-1 \\
56-69\end{array}$ & $\begin{array}{l}395- \\
18-1 \\
61-70\end{array}$ & $\begin{array}{l}395 \mathrm{~A}- \\
15-5 \\
0-11\end{array}$ & $\begin{array}{l}395 \mathrm{~A}- \\
63-1 \\
108-116\end{array}$ \\
\hline $\begin{array}{l}\mathrm{SiO}_{2} \\
\mathrm{TiO}_{2} \\
\mathrm{Al}_{2} \mathrm{O}_{3} \\
\mathrm{Fe}_{2} \mathrm{O}_{3} \\
\mathrm{FeO} \\
\mathrm{MnO} \\
\mathrm{MgO} \\
\mathrm{CaO} \\
\mathrm{Na}_{2} \mathrm{O} \\
\mathrm{K}_{2} \mathrm{O} \\
\mathrm{P}_{2} \mathrm{O}_{5} \\
\mathrm{H}_{2} \mathrm{O}^{+} \\
\mathrm{H}_{2} \mathrm{O}^{-}\end{array}$ & $\begin{array}{r}48.47 \\
1.00 \\
16.93 \\
3.25 \\
4.78 \\
0.14 \\
8.94 \\
11.92 \\
2.30 \\
0.14 \\
0.11 \\
1.40 \\
0.60\end{array}$ & $\begin{array}{r}47.45 \\
0.35 \\
16.73 \\
1.15 \\
4.95 \\
0.11 \\
11.62 \\
8.99 \\
3.61 \\
0.21 \\
0.02 \\
4.48 \\
0.33\end{array}$ & $\begin{array}{r}40.57 \\
0.01 \\
0.74 \\
5.55 \\
5.17 \\
0.11 \\
40.27 \\
0.84 \\
0.02 \\
0.02 \\
0.01 \\
6.38 \\
0.30\end{array}$ & $\begin{array}{r}48.56 \\
1.12 \\
19.43 \\
2.04 \\
5.63 \\
0.11 \\
6.98 \\
12.03 \\
2.48 \\
0.09 \\
0.14 \\
1.02 \\
0.38\end{array}$ & $\begin{array}{r}49.53 \\
1.08 \\
17.53 \\
1.97 \\
5.77 \\
0.13 \\
8.13 \\
12.07 \\
2.14 \\
0.09 \\
0.09 \\
1.32 \\
0.16\end{array}$ \\
\hline Trace e & nents ( $p p$ & \multicolumn{4}{|c|}{ L } \\
\hline $\begin{array}{l}\mathrm{Rb} \\
\mathrm{Sr} \\
\mathrm{Zr}\end{array}$ & $\begin{array}{l}8 \\
122 \\
105\end{array}$ & $\begin{array}{l}7 \\
313 \\
88\end{array}$ & $\begin{array}{l}<1 \\
3 \\
42\end{array}$ & $\begin{array}{l}<1 \\
144 \\
92\end{array}$ & $\begin{array}{l}7 \\
123 \\
87\end{array}$ \\
\hline
\end{tabular}

altered olivines, and veins. Very rare euhedral lowquartz crystals occur in vugs filled with saponite.

Alteration of olivine is most prominent in the coarse-grained parts, but exceptions do occur. Minerals 
replacing olivine are saponite, phillipsite, calcite, "limonite," and goethite. There is a weak positive correlation between the degree of alteration, $\mathrm{H}_{2} \mathrm{O}^{+}$content, and $\mathrm{Fe}_{2} \mathrm{O}_{3} / \mathrm{FeO}$ ratios (see Figure 4).

\section{CHEMISTRY}

\section{Methods}

All analyses were made on an X-ray spectrometer, sample presentation being in the form of pressed glass powder tablets. Primary standards USGS W-1, ZGI B.M., CSRM MRG-1, USGS PCC-1, NIM N, NIM D., as well as secondary in-house standards, were used as reference samples. Measurements on shipboard calibration standards 395A-15-5, 0-11 cm, 395A-63-1, 108$116 \mathrm{~cm}, 395-17-1,56-59 \mathrm{~cm}$, and $395-18-1,61-70 \mathrm{~cm}$ are included in Table 2.

$\mathrm{Na}_{2} \mathrm{O}$ and $\mathrm{K}_{2} \mathrm{O}$ values as well as $\mathrm{Rb}$ contents of the dolerites were determined on a flame photometer coupled to a lock-in amplifier (Cammann, 1972). FeO was determined using a Teflon digestion vessel under nitrogen atmosphere. The digested sample was titrated with potassium dichromate, the end point being determined with an electrode coupled to an automatic titrator/potentiograph. $\mathrm{H}_{2} \mathrm{O}$ (total) was extracted at $1600^{\circ} \mathrm{C}$ with an induction furnace and carried over to a Karl-Fischer titrator with nitrogen.

\section{Analytical Results}

Individual dolerite analyses are shown in Table 2. Average compositions of the dolerites, phyric and aphyric basalts, as well as for the basal chilled margin of the lower dolerite unit, are included in Table 3. The phyric basalt average includes geochemical units $\mathrm{P}_{2}, \mathrm{P}_{3}, \mathrm{P}_{4}$ and $\mathrm{P}_{5}$. Compositionally, the dolerites can be readily distinguished from the aphyric basalts through their lower $\mathrm{TiO}_{2}, \mathrm{Fe}_{2} \mathrm{O}_{3}, \mathrm{FeO}, \mathrm{Na}_{2} \mathrm{O}$, and $\mathrm{K}_{2} \mathrm{O}$, and higher $\mathrm{Al}_{2} \mathrm{O}_{3}, \mathrm{MgO}$, and $\mathrm{CaO}$ contents. The differences between the dolerites and the phyric basalts are generally limited to the lower $\mathrm{Al}_{2} \mathrm{O}_{3}$ and $\mathrm{MgO}$ contents of the latter.

As is shown in the A-F-M plot (Figure 2), the basal chilled margin (8), average dolerite (7), phyric (6), and aphyric (4) basalt compositions from Hole 395A are arranged, in the same order of succession, roughly parallel to, and in the direction of, the usual tholeiitic differentiation trends. The compositional fields of the aphyric (a) and phyric (b) units overlap slightly,

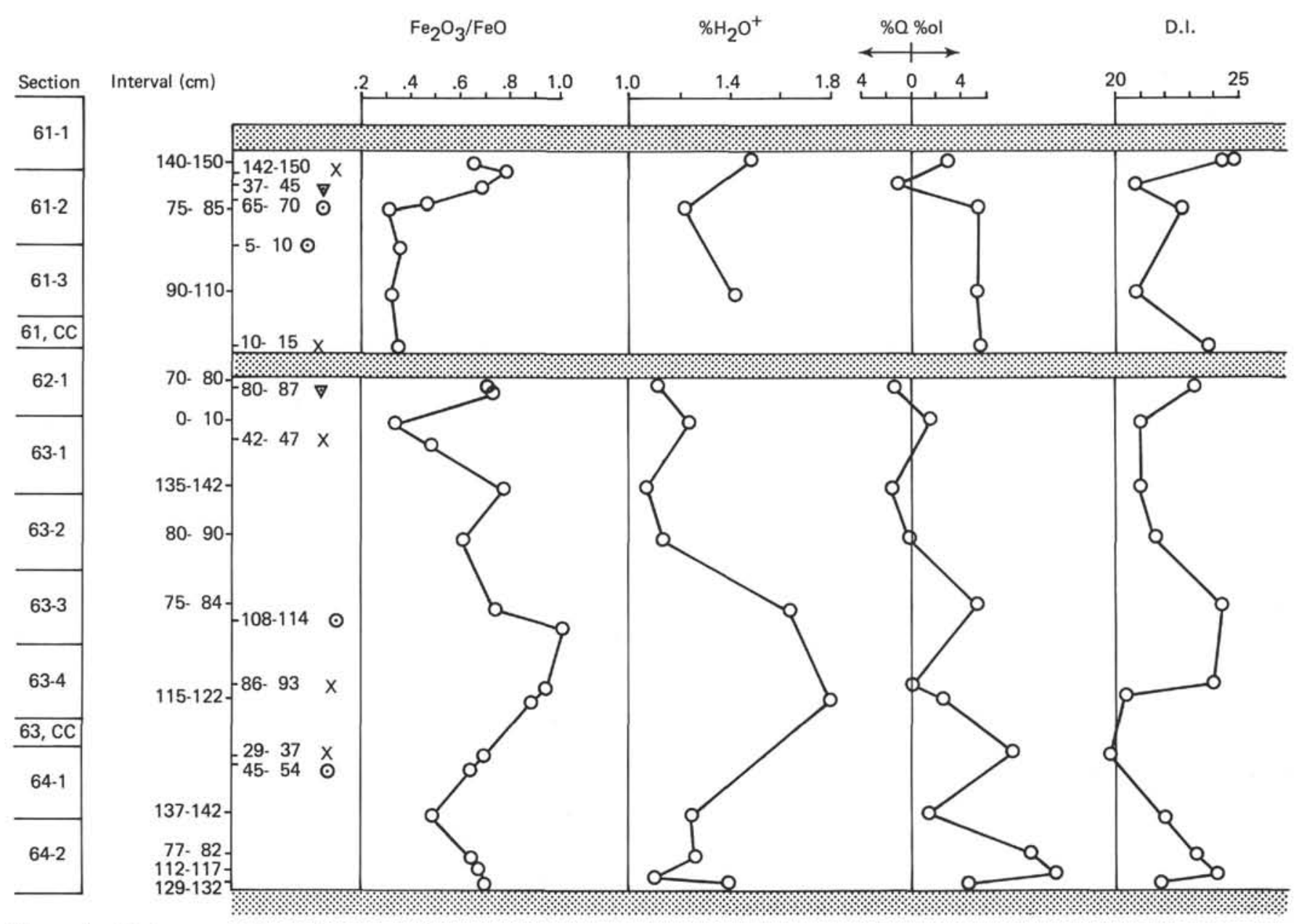

Figure 4. Variation of $\mathrm{Fe}_{2} \mathrm{O}_{3} / \mathrm{FeO}, \mathrm{H}_{2} \mathrm{O}^{+}$, normative olivine and quartz and the differentiation index through two sills. Sample numbers to the left are from Munich collection, those on the right are from Bougault $(\nabla)$, Rhodes $(\times)$, and Zolotarev (๑), this volume. 
TABLE 3

Average Compositions (in per cent) of Dolerite and Phyric and Aphyric Basalts, Compared to Chilled Basal Dolerite (Sample 64-2, 129-132 cm)

\begin{tabular}{lrrrr}
\hline Rock Type & $\begin{array}{c}\text { Chilled } \\
\text { Margin } \\
\text { Dolerite }\end{array}$ & Dolerite & $\begin{array}{r}\text { Phyric } \\
\text { Basalt }\end{array}$ & $\begin{array}{r}\text { Aphyric } \\
\text { Basalt }\end{array}$ \\
\hline No. of Analyses & \multicolumn{1}{c}{1} & \multicolumn{1}{c}{12} & \multicolumn{1}{c}{22} & \multicolumn{1}{c}{24} \\
\hline $\mathrm{SiO}_{2}$ & 48.39 & 48.60 & 48.82 & 48.51 \\
$\mathrm{TiO}_{2}$ & 1.00 & 1.10 & 1.20 & 1.66 \\
$\mathrm{Al}_{2} \mathrm{O}_{3}$ & 16.90 & 16.83 & 17.56 & 15.12 \\
$\mathrm{Fe}_{2} \mathrm{O}_{3}$ & 3.25 & 2.99 & 2.90 & 3.79 \\
$\mathrm{FeO}$ & 4.78 & 5.29 & 5.38 & 6.20 \\
$\mathrm{MnO}$ & 0.14 & 0.14 & 0.14 & 0.17 \\
$\mathrm{MgO}$ & 8.92 & 8.16 & 7.29 & 7.67 \\
$\mathrm{CaO}$ & 11.90 & 12.00 & 12.24 & 10.61 \\
$\mathrm{Na}_{2} \mathrm{O}$ & 2.30 & 2.47 & 2.50 & 2.80 \\
$\mathrm{~K}_{2} \mathrm{O}$ & 0.14 & 0.12 & 0.14 & 0.23 \\
$\mathrm{P}_{2} \mathrm{O}_{5}$ & 0.12 & 0.10 & & \\
$\mathrm{H}_{2} \mathrm{O}^{+}$ & 1.40 & 1.31 & 0.97 & 1.14 \\
$\mathrm{H}_{2} \mathrm{O}^{-}$ & 0.60 & 0.62 & 0.53 & 0.84 \\
$\mathrm{FeO} \mathrm{Tot.}$ & 7.70 & 7.99 & 7.98 & 9.61 \\
$\mathrm{Fe}_{2} \mathrm{O}_{3}$ & 0.68 & 0.56 & 0.54 & 061 \\
${ } }$ & & & & \\
$\mathrm{Mg}$ & 0.67 & 0.64 & 0.62 & 0.59 \\
$\mathrm{Mg}+\mathrm{Fe}$ & & & & \\
\hline
\end{tabular}

whereas the dolerites (c) are to a large extent enclosed in the compositional field of the phyric basalts, thus demonstrating the chemical affinity of the latter two rock types.

The molecular $\mathrm{Mg} / \mathrm{Mg}+\mathrm{Fe}_{\text {total }}$ ratios for the chilled margin, average dolerites, and phyric and aphyric basalts follow much the same pattern as depicted in the A-F-M diagram. Corresponding values are 0.67 , $0.64,0.62$, and 0.59 , respectively. The basal chilled margin thus represents the most primitive of these units.

Distribution trends of the major oxides and normative minerals (and modes) in the upper and lower dolerite sills are generally erratic (see Figure 4). This is reflected in the behavior of the Differentiation Index (D.I.) and normative olivine (and quartz) trends (Figure 4). The olivine-quartz trend, although exhibiting a net increase in normative olivine towards the basal chilled margin, shows variations of up to about 8 per cent between the neighboring samples. The increase in normative olivine may be a consequence of crystal settling effects too weak to have produced an olivinerich layer but suggesting enrichment tendencies. Clinopyroxene crystals are too scarce to have produced, or permit detection of, any enrichment effects. Pronounced compositional variations in Sections 63-3 and 63-4 (see Figure 4) correspond to increases in secondary mineral content and to the presence of brecciated zones in this part of the lower sill.

\section{Summary}

Effects of differentiation (crystal sinking or floating, migration of residual or immiscible melts) are very limited (sinking of olivines) or even undemonstrable (sinking of clinopyroxene, floating of plagioclase, migration of residual or immiscible melts). The effects of differing cooling rates are, however, clearly developed: gradually increasing grain size in the groundmass, segregation of a (immiscible?) melt in the median portions of the two units, now represented by the mesostasis, and a more extensive hydrothermal mineralization in the middle of the lower dolerite unit.

\section{REFERENCES}

Bhattacharji, S., 1967. Mechanics of flow differentiation in ultramafic and mafic sills, J.Geol., v. 75, p. 101-102.

Cammann, K., 1972., Aufbau eines extrem empfindlichen Flammenfotometers für Analysen im Picogramm-Bereich mit Hilfe eines "lock-in" Verstärkers, Messtechnik, v. 9, p. 272-277.

Jaeger, J. C., 1968. Cooling and solidification of igneous rocks. In Hess, H. H. and Poldervaart, A. (Eds.), Basalts, v. 2: New York (J. Wiley and Sons), p. 503-536.

Prinz, M., Keil, K., Green, J. A., Reid, A. M., Bonatti, E., and Honnorez, J., 1976. Ultramafic and mafic dredge samples from the equatorial Mid-Atlantic Ridge and fracture zones, J. Geophys. Res., v. 81, no. 23, p. 4087-4103.

Shaw, H. R., 1965. Comments on viscosity, crystal settling and convection in granitic magmas, Am. J. Sci., v. 263, p. $120-152$ 